\title{
広重の描いた『名所江戸百景』にみる水辺空間の構成 に関する研究
}

\author{
A Study of Composition of Riverside Space in "One Hundred Edo Noted Place Pictures" Painted by \\ Hiroshige
}

\author{
須藤 訓平* 渡部 一二** \\ Kumpei SUTOU Kazuji WATABE
}

\begin{abstract}
Ukiyoe of the Edo period was the first common people art that their vitality had produced. It was the only mass media which supported the people's amusement, education, and fashions. We noticed that riverside was drawn in $76 \%$ of the Ukiyoe prints in "One Hundred Edo Noted Place Pictures" that was very popular among Edo people. And We analyzed "riverside space compon ents" liked by Edo people in the prints. We extracted seven "riverside space components" (space expression domain, key Line, four seasons, mountain, breakwater form, plants, construction) and three "noted place components" (natural features spot system, seasons and years system, subject system) which were common to the traditional painting technique of the Japanese paintings, from the prints. We clarified the correlation between them. As a result, the riverside space compositions, that was mostly used in the prints was the one that the pine was planted in the bank, and the bridge was built. This simple riverside space composition was a flexible space structure, in which people were able to receive the annual events, history, and natural features of the season, such as evergreen pine and scattered cherry blossoms.
\end{abstract}

Keywords: edo, noted place, riverside, desing, hirosige キーワード：江戸，名所，水辺空間，デザイン，広重

1.はじめに

\section{(1) 研究の背景と目的}

江戸期の浮世絵は，民衆の活力が生み出した最初の庶民芸術2 であり，庶民の娛楽，教養，流行を支える唯一のマスメディアと して，その中心的な役割を果たしていた。特に汇戸後期に広重が 描いた『名所江戸百景』（以後, 「江戸百景」）は, 広重の実在性 を改め美化するという描写力 ${ }^{1)}$ により名所を見事に描き江戸庶民 の人気を博した。浮世絵版画は, 江戸人の興味の対象を把握する 貴重な史料と捉えることができる。

「江戸百景」絵図には，119 点中，93 点（約 79\%）に水辺が

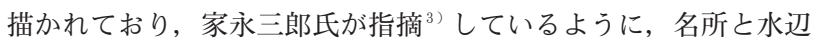
の緊密な関係性が読み取れる。絵図を用いた江戸期の水辺空間研 究には, 橋本政子氏・堀繁氏 $\left.\left.{ }^{4}, 5\right), 6\right)$ の一連の研究や江戸庶民の 行動之水辺に関する研究 7 などが挙げられるが, 浮世絵図を史料 とし，水辺を江戸庶民が眺め，楽しむなどの行為媒体（以下，鑑 賞媒体という）に視点を合わせた研究はみられない。江戸は, 飛 鳥山など幕府によって積極的に行楽地が整備され, 四季を通して 多様な年中行事が行なわれていた。「名所の景観美」が 100 万人 の都市を維持するための生活調整空間, 庶民の自己解放の場とし て貴重な都市機能の役割を果たしていた時代であった。しかし， 現代の都市計画や景観形成をテーマにデザインされた空間は, 法 的制限, 経済優先や機能性を重視し, 人間の本性が求める豊かさ, 潤い, 癒し, 歴史・文化性に対する配慮が少ない計画論が主流を 成していると指摘できる。本研究は, 『江戸百景』に描写されて いる豊かな「人と自然環境の交流」を可能にした水辺空間の特性 を明らかにし, 現代の都市づくりの方向性において人間本来の景 観形成に江戸期の絵図で表現された水辺空間の魅力と新たな基礎 的指標を見出すことを目的とする。この目的を達成するため, 江 戸庶民と景観の交流を巧みに描いた「江戸百景」中に描写された 水辺空間要素に焦点を当て, 水辺空間を構成している基礎的な空 間構成要素：ハード要素（i ）【水辺空間構成要素】と，伝統的 絵画技法に見られる水辺空間を構成する山水, 歳時などの景物要 素：ソフト要素（ii）【水辺の名所構成景物要素】の 2 要素に分 類し，その相関性を抽出して分析をおこない，各要素間の特性に 関する考察を行なっている。

\section{（2）分析対象絵図の位置づけ}

歌川広重之並んで江戸期の代表的風景画家の一人に葛飾北斎が 挙げられる。北斎絵画の特徵について，宮尾しげお氏は，「洋画 に教わることが多く今までの人々が考えていた図柄ではなく非常 な創造力によるものが多い。ともすると常軌からはずれるような 図柄になり広重の描写力より一段ときびしいものがあったため広 重ほどの人気は出なかった」尚と述べている。江戸人に好まれた 水辺名所に扔ける特性を分析するため，分析対象は文化的に成熟 した江戸時代後期に描かれた水辺の名所絵であること，四季を通 して江戸庶民の情緒を風景に盛り込み，さらに，色彩豊かに実在 性を有し, ランドスケープ構成要素を詳細に表現した絵図であり, 唯一のマスメディアとして中心的役割を果たした浮世絵版画であ ることに留意し，歌川広重「名所江戸百景」を分析対象とした。

\section{2. 研究と分析の方法}

(1) 研究対象絵図について

「江戸百景」 119 点中，水辺空間が描かれた絵図（93 点）から， 江戸境界基準・朱引内 ${ }^{8}$ に属した絵図 78 点（以降，調査対象絵 図）に限定し分析を行った。

\section{（2）絵図の分析方法}

調查対象絵図から（i ）【水辺空間構成要素】A 空間表現領域, $\mathrm{B}$ 軸線, $\mathrm{C}$ 四季, $\mathrm{D}$ 山, $\mathrm{E}$ 護岸形態, $\mathrm{F}$ 植栽, $\mathrm{G}$ 構築物, (ii) 【水辺の名所構成景物要素】 $\mathrm{H}$ 名勝系, $\mathrm{I}$ 歳時系, $\mathrm{J}$ 主題系 (歴 史文化) の大きくは 2 要素 $(\mathrm{i} \sim \mathrm{ii})$, 詳しくは 10 要素 $(\mathrm{A} \sim \mathrm{J})$ の風景要素を抽出し, 表一 1 にまとめ, 10 要素を対象としたク口

"多摩美術大学大学院環境デザイン科 **多摩美術大学環境デザイン科 
ス分析を行なった。以下，各風景要素について説明する。

(i )【水辺空間構成要素】(表 $-1-$ ( i ))

絵図中に描かれている水辺を構成する基本的な風景要素として

水辺の空間性・場所性に関する A 空間表現領域, B 軸線, C 四
季, $\mathrm{D}$ 山, $\mathrm{E}$ 護岸形態, $\mathrm{F}$ 植栽, $\mathrm{G}$ 構築物の 7 要素に分類し，そ の総称を水辺空間構成要素と命名した。以下，各要素について記 す ( 7 要素 : $A \sim G)$ 。

$\mathrm{A}$ 空間表現領域（表 $-1-(\mathrm{i})-\mathrm{A}$ )

表 -1 『名所江戸百景』にみる水辺空間構成要素及び, 水辺の名所構成景物要素の分類表

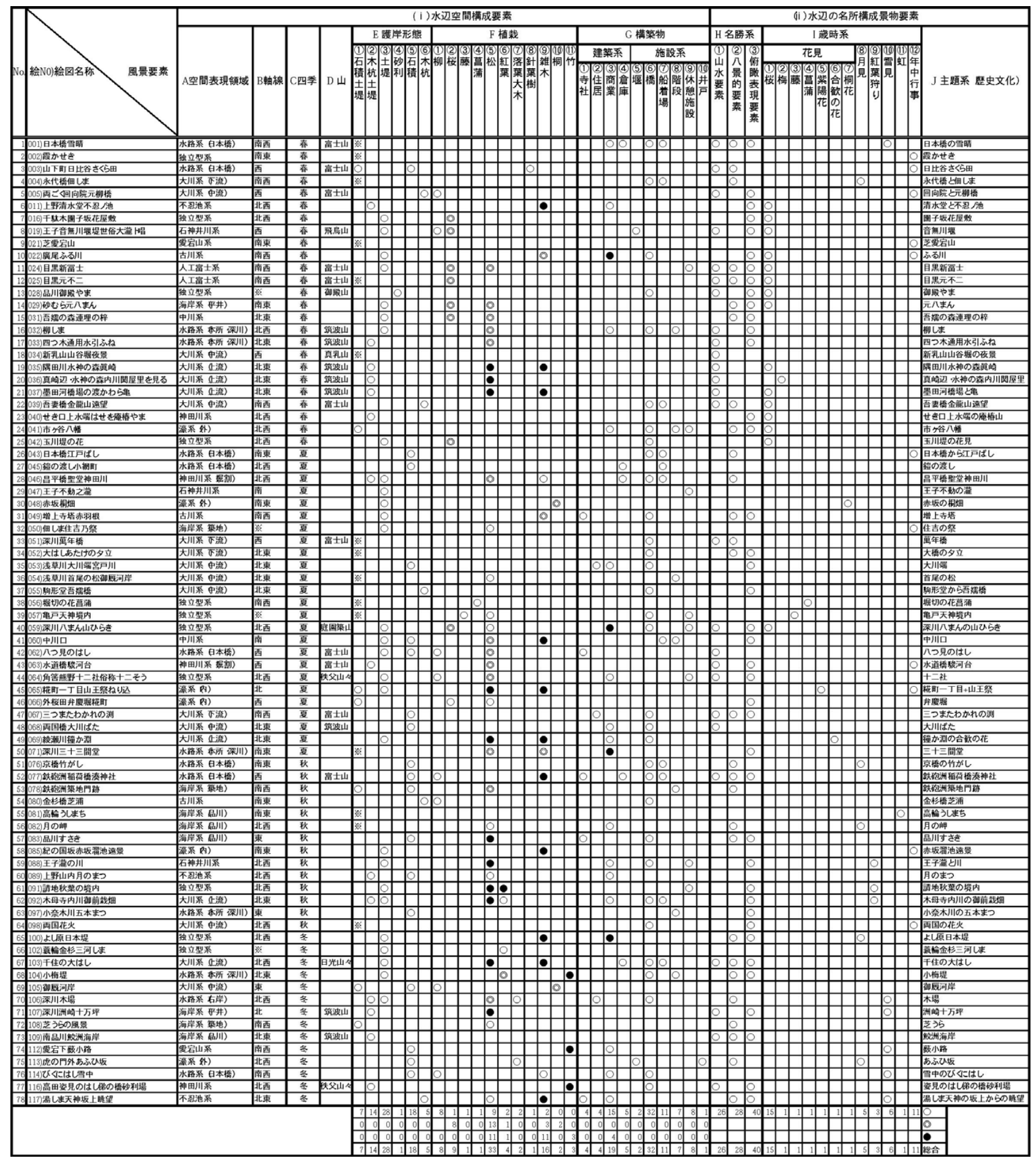

表 -2 水辺空間構成要素の中の $A \sim D$ までの各集計表

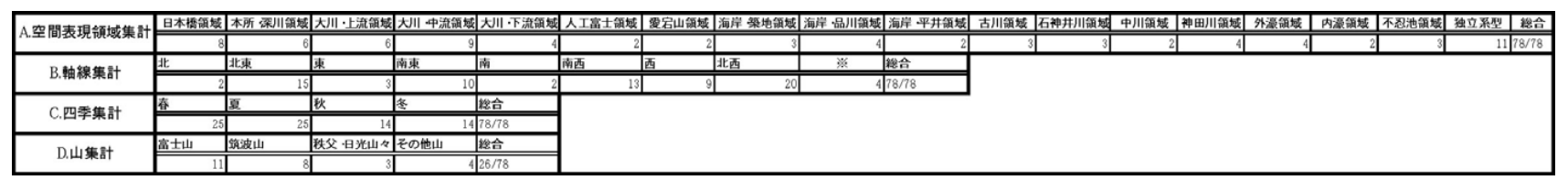




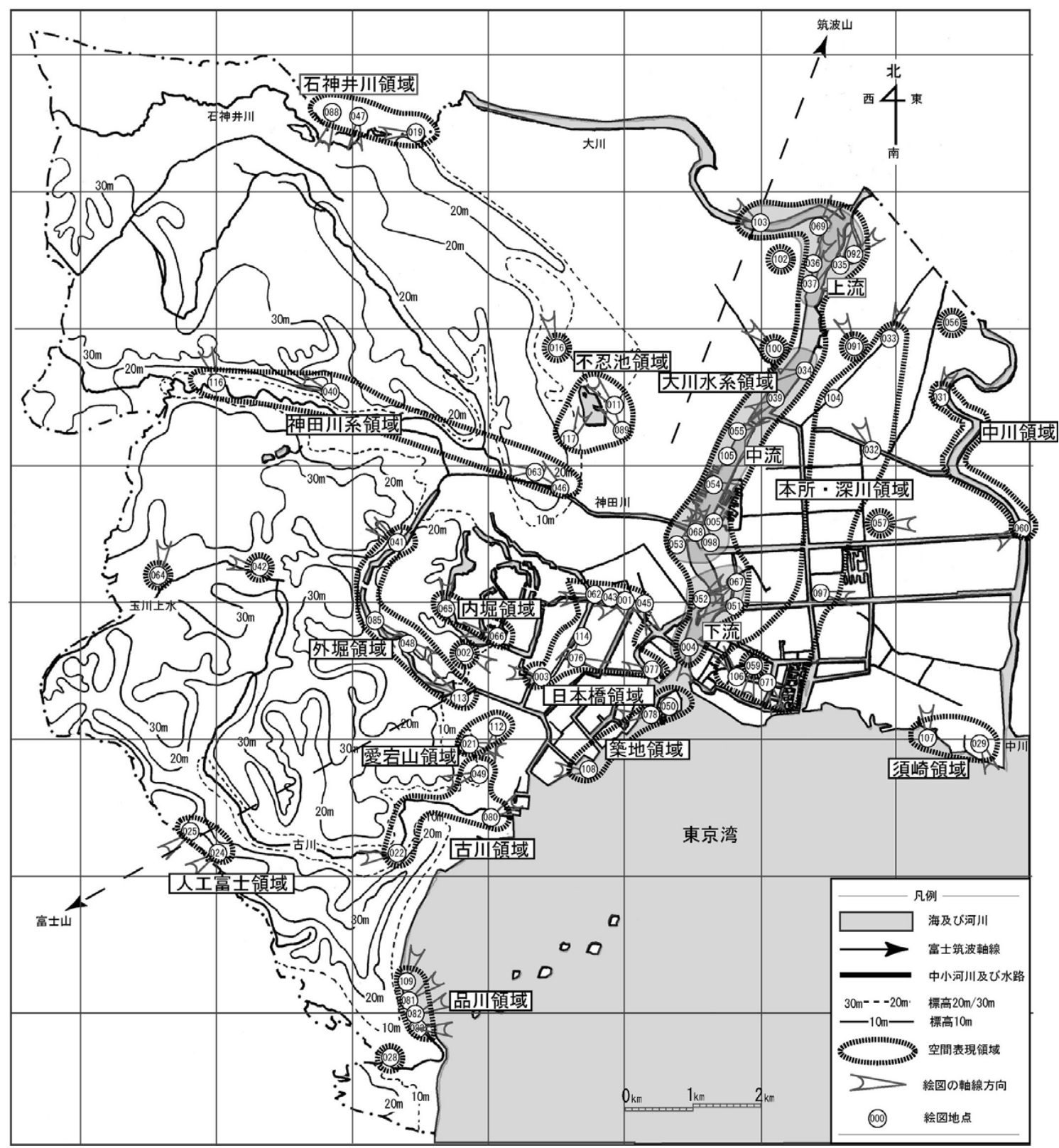

調查対象絵図に 描かれた水辺空 間地点を図-1 にプロットし，

1. 同水系 (水 路, 河川, 池, 海岸の 4 系）上 に位置する。2 . 同地形 (標高 $10 \mathrm{~m}, 20 \mathrm{~m}, 30$ $\mathrm{m}$ の 3 等高線を 基準)上に位置 する。 3 . 絵図 主題 (画の景物) の一部に共通性 が認められる。 4. 描かれた絵 図の地点が直径 $1 \mathrm{~km}$ 以内にそ れぞれが隣接す る。上記 4 項目 中, 3 項目以上 該当する絵図を グルーピングし, 以下, 18 領域 にまとめ表 -1 に表示した。表一 $1-(\mathrm{i})-\mathrm{A}$ ま た, 18 領域の 詳細位置につい ては, 図-1に 示した。

18 領域名称： 日本橋領域, 本 所深川領域, 大 川上流領域：白 䰅ノ渡から千住 大橋付近, 大川 中流領域：両国

図ー1『名所江戸百景』絵図描写ポイント及び空間表現領域図 橋付近加竹屋

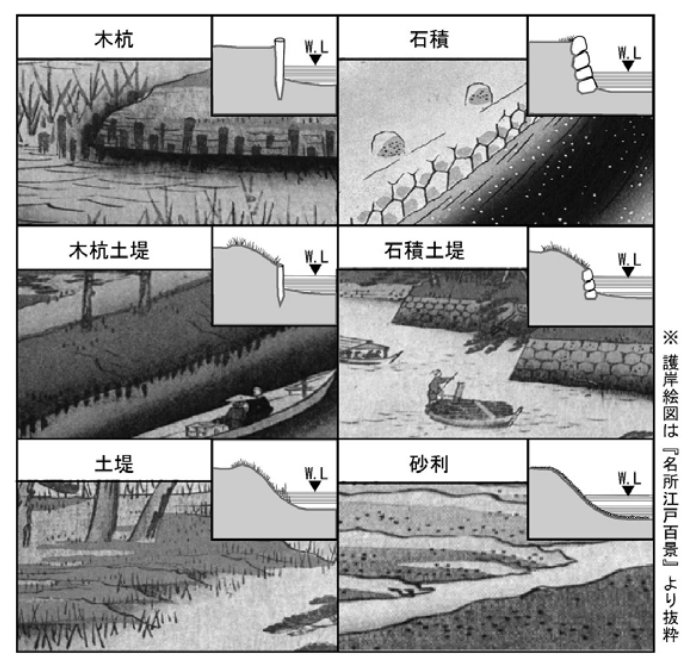

図－2『名所江戸百景』に描かれた護岸形態図

八渡近，大川下流領域：永代橋加ら橋付近，石神井川領域，中 川領域, 古川領域, 神田川領域, 築地領域, 品川領域, 須崎領域, 外濠領域, 内濠領域, 不忍池領域, 人工富士領域, 愛宕山領域, 独立型系領域。

$\mathrm{B}$ 軸線（表 $-1-(\mathrm{i})-\mathrm{B})$

軸線とその表現範囲は, 絵図に描かれている地形, 水系, 山や

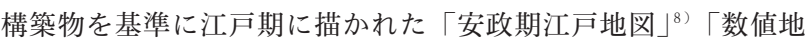
図 $1 / 25000\lrcorner^{9)}\left\lceil\right.$ 東京近傍中部 $1 / 20000 」^{10)}$ と照合し, 総合的に 判断し，中心軸線を基準に東西南北をさらに $45^{\circ}$ で区分した 8 万 の軸線で分類を行ない表 $-1-$ （i ）-B にそれぞれ北・北東・東・ 南東・南・南西・西・北西・北と明記した。

$\mathrm{C}$ 四季 $($ 表 $-1-(\mathrm{i})-\mathrm{C})$

「名所江戸百景：目次」に用いられた春夏秋冬をそのまま表一 $1-$ ( i ) - C に明記した。

$\mathrm{D}$ 山（表- $1-(\mathrm{i})-\mathrm{D})$

調查対象絵図中の富士，筑波，秩父，日光の遠望の山々と，庭 園築山，飛鳥山，御殿山，真乳山，元富士，新富士などの江戸朱 引内に存在する近望の山々を表一 $1-$ （ i ）－Dに明記した。 


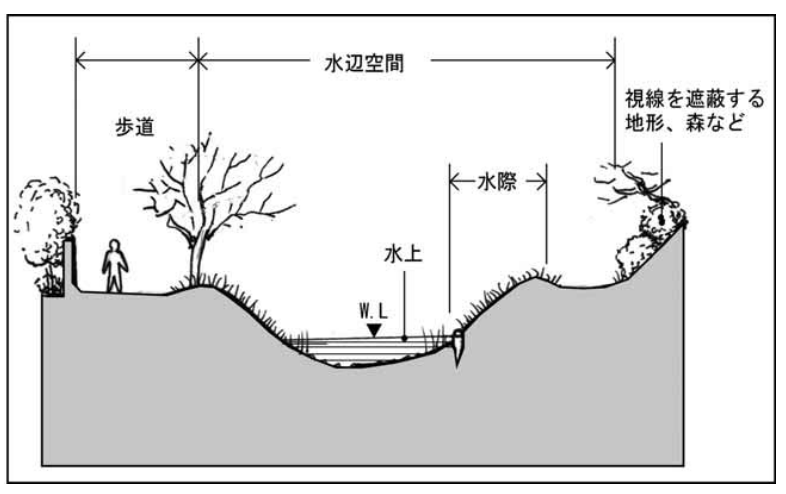

図－3＼cjkstart調査対象絵図における水辺空間領域概念図

$\mathrm{E}$ 護岸（表 $-1-(\mathrm{i})-\mathrm{E})$

調查対象絵図の水辺護岸形態を調べた所, (1)石積土堤, (2)木杭 土堤, (3)土堤, (4)砂利堤, (5)石積, (6)木杭の 6 タイプに整理でき た。両岸で護岸様式が異なる絵図や, 片岸に 2 形態の護岸が確認 できる絵図も認められるため, 一枚の絵図から二点以上の護岸形 態をむつ絵図についても表- $1-(\mathrm{i})-\mathrm{E} に \bigcirc$ 印で表示した。描 写技法によって護岸形態を確認できなかった絵図については, 正 確な分析が困難なため, 測定不能 (※マーク) とした。また, 護 岸に構造上, 橋や階段を石積としている場合が認められるが，橋 下，階段等の施設は，護岸形態の対象外とした。

$\mathrm{F}$ 植栽 (表 $-1-(\mathrm{i})-\mathrm{F})$

水辺空間に限定した調查のため, 調查対象を水辺空間領域内（図一 3）に描写されている植栽に限定した抽出を行なった。抽出の結 果, (1)柳, (2)桜, (3)藤, (4)菖蒲, (5)松, (6)紅葉（紅葉している表 現が認められる木の総称), (7)落葉高木 (榎, 欅など), 8針葉樹, (9)雑木 (落葉木で明確な種名が確認できない木の総称), (10桐, (11)竹の 11 樹木が確認できた。また, 絵図によっては, 並木 (○), 独立木 $(\bigcirc)$, 林 (O) の 3 形態が認められたため, 表-1-(i )F に上記印で表示した。

$\mathrm{G}$ 構築物 (表 $-1-(\mathrm{i})-\mathrm{G})$

水辺空間に限定した調査を行なうため, 調査対象を水辺空間領 域内 (図-3) に限定し, 建築系構造物及び施設系構造物の抽出 を行なった。

その結果, 建築系構造物は, (1)寺社 (武家屋敷, 寺院, 江戸城施 設を含む）(2住居, (3)商業, (4)倉庫の 4 要素, 施設系構造物は, (5)堰，(6)橋，(7)船着場，(8)階段，(9)休㲡施設，(10井戸の 5 要素, 合計 10 要素を抽出し, 表 $-1-(i)-G$ に○印で記録した。ま た, 仮設要素を含む建築（本研究では, 建築の四方に壁面がない 東屋的建築）は（○）で表示した。

（ii）【水辺の名所構成景物要素】(表 $-1-$ (ii ))

日本における伝統的絵画技法は, 中国神仙思想における山水の 視点が意識化され, 平安期に和歌, 文学と融合した大和絵 ${ }^{4)}$ が唐 絵の模写から登場する。また, 雪舟の「天橋立」の俯瞰表現は, 近世初期風俗画における「洛中洛外図屏風」にも表現され, 平安 時代以来の「名所絵」「月次絵」「四季絵」の系列に属した「大和 絵」の影響が認められる。

中国から伝来された「八景」は，「特に徳川時代に入ると，八 景のないところは一ヶ所むないといわれるくらい日本のいたると ころで八景が選ばれ, 日本中に展開される画題となっていっ た ${ }^{122}$ 。そうした一連の定型としての風景画は, 江戸期に入り, 積 極的に画家自ら画題を見ることが可能になり, 画家自身の個性で 写実的描写等が描かれ, 次第に広重風景画は, 古来の名所絵の伝 統と共に「厳格な写実的基礎を有する風景表現を確立していった」。 成瀬不二雄氏は, 「広重絵画における風景版画が平安時代以来の 名所絵の伝統を継承しており, その芸術の特色は伝統的な美意識

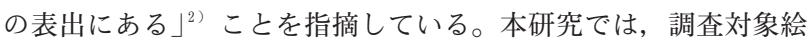
図にみる伝統的絵画技法を「水辺の名所構成景物要素」と命名し, 以下, $\mathrm{H}$ 名勝系, $\mathrm{I}$ 歳時系, $\mathrm{J}$ 主題系（歴史文化）の 3 要素, 詳 しくは 16 要素に分け, 景物要素の抽出を行なった（以下 3 要素： $\mathrm{H} \sim \mathrm{J})$ 。

$\mathrm{H}$ 名勝系要素 $($ 表 $-1-($ ii $)-\mathrm{H})$

(1)山水要素, (2)八景的要素, (3)俯瞰表現要素を名勝系要素之命 名し, 表 $-1-$ （ii ) - H に表示した。以下各要素について説明 をする。

(1)山水要素 (表 $-1-$ (ii ) $-\mathrm{H}-$ (1)

調查対象絵図中で，画中に風景要素として山と水辺が同一画面 に描かれている絵図を「山水」要素を有すると位置付け, 表 $-1-$ (ii) $-\mathrm{H}$-11に○印で表示した。

(2)八景的要素 (表-1-(ii) - H- (2))

調査対象絵図の中で, 以下 8 つ風景要素が描かれている絵図 を「八景的要素」を有すると位置付け, 表- 1 - (ii) - H一- (2)に ○印で表示した。以下，八景的要素の抽出条件について記す。落 雁：雁のように $\mathrm{V}$ 字型の飛行をする鳥群が描写されている絵図。 帰帆：帆掛け舟が夕暮れの水辺に浮いている風景が描写されてい る絵図。晴嵐：山里が山霞に煙ってかすみ見える風景が描写され ている絵図。暮雪：日暮れの水辺に舞い降る雪が描写されている 絵図。秋月：秋の月が描写されている絵図。夜雨：夜に降る雨が 描写されている絵図。晚鐘 : 夜の風景の中に鐘が描写されている 絵図。夕照: 夕焼けの中で, 漁をしている風景が描写されている 絵図。

(3)俯瞰表現要素（表-1-(ii) - H- (3)

調查対象絵図中で画面構図の位置が描かれている人物を基準に 描写地点が浮遊（地面からある高さに上がった所）した視点で風 景を見下万す形で表現された絵図を俯瞰表現が認められる絵図と して表-1-（ii）-H-(3)に○印で表示した。

I歳時系 (表 $-1-($ ii $)-I$ )

調査対象絵図中に「大和絵」の系列に属した「月次絵」「四季 絵」に該当するものを歳時系として取り上げた結果, 以下 12 要素 を抽出し，表一 1 - (ii) - Iに○印で表示した。

(1)花見：桜，(2)花見：梅，(3)花見：藤，(4)花見：菖蒲，(5)花見： 紫陽花，(6)花見：合歓花，(7)花見：桐花，8)月見，9紅葉狩り， (10)雪見, (11)虹, 12年中行事（祭り, 正月, 鯉幟など)

$\mathrm{J}$ 歴史文化（表 $-1-($ ii $)-J$ )

調査対象絵図画題は, その土地の歴史・文化之密接な関わりが 認められるため, 画題の主要テーマを抜粋し, 表- $1-$ - (ii ) - J に表示した。

\section{3. 分析結果及び考察}

\section{(1) 江戸の基本的な水辺空間の構成について}

調查対象絵図に打ける江戸の水辺空間特徵について明らかにす るため, 水路空間領域内 $($ 図 - 3) に属する表 -1 （i ）の【水辺 空間構成要素】に限定し, $\mathrm{A}$ 空間表現領域, $\mathrm{B}$ 軸線, $\mathrm{C}$ 四季, $\mathrm{D}$ 山, $\mathrm{E}$ 護岸, $\mathrm{F}$ 植栽, $\mathrm{G}$ 構築物中で多数描かれた上位要素につい て分析を行なった。A 水辺空間表現領域の 18 領域中, 最も多く 描かれた領域は, 大川中流領域 9 点, 次いで日本橋領域 8 点, 本 所・深川領域 6 点, 大川上流領域 6 点であった。 B 軸線（表- $1-$ (i ) -B) 最多数描かれた軸線は, 北西 20 点ついで, 北東 15 点, 南西 13 点である。北西方向を最多数描いた空間表現領域は，独 立型系領域であった $(30 \%: 6 / 20$ 点)。近世の地域図が，地域の 地形環境に応じて, もっとも見やすく, 描きやすい方向をもって 描かれている ${ }^{13)}$ ことに着目すると, 北西方向は, $30 \mathrm{~m}$ 等高線が集 中しており，江戸内においても安定した形を仰ぎ見ることが可 能 ${ }^{13)}$ な地点が多く存在し, 比較的, 構図が安定した描写しやすい 


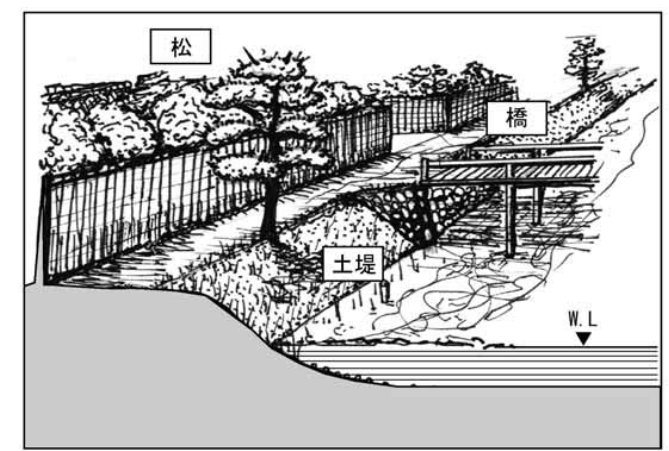

図-4 調査対象絵図にみる基礎的水辺空間要素集合図

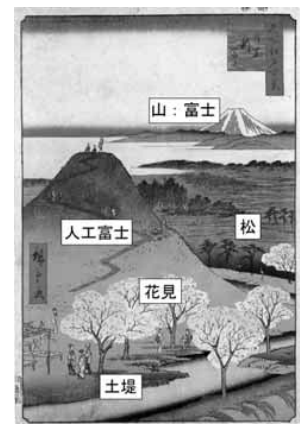

絵図一 | 11：目黒新富士

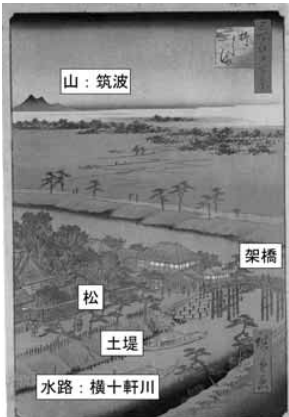

絵図一－2 16:柳しま

方向であったように思われる。C 四季（表－1-（i ）－C）春・ 夏が共に 25 点, 秋・冬が共に 14 点描かれており, 春・夏に水辺 名所が集中している。また，春・夏を多数描いた空間表現領域は， 大川中流領域（14\%:7/50 点）であった。D山（表-1-（i ）D) 最多数描かれた山は，富士山 11 点，次に筑波山 8 点である。 富士山が多数描かれた空間表現領域は，日本橋領域（約 36\%:4 /11 点）であった。富士・筑波については，（3）－（i ）山水要 素を骨子にした分析結果で述べる。 E 護岸形態（表－1 - （i ）E) 多数順に, 土堤 28 点, 石積 18 点, 木杭土堤 18 点が描かれ ており, 調查対象絵図中で最も多用された水辺護岸形態は土堤 (約 36\%) である。多数描かれた空間表現領域は, 独立型系領域 (25\%:7/28 点) であった。 F 植栽（表 $-1-(\mathrm{i})-\mathrm{F}$ ) 最多数 描かれた植栽は, 松 33 点次いで, 雑木 16 点, 桜 9 点があげら れ, 調查対象絵図中で最多用された植栽は, 松（約 42\%）であっ た。また，松を多数描いた空間表現領域は大川上流領域（約 18 $\%: 6 / 33$ 点) であった。 $\mathrm{G}$ 構築物（表 $-1-(\mathrm{i})-\mathrm{G}$ ) 最多数 描かれた構築物は, 橋 32 点次いで, 商業施設 19 点休喤施設 8 点 が多く描かれ, 調查対象絵図中で最も多用された構築物は, 橋 （約 41\%）であった。また, 多数描いた空間表現領域は日本橋領 域・大川中流領域の 2 領域（共に約 16\%: 5/32 点）であった。

上記から, 空間表現領域ごとに水辺空間構成に特徵があること がうかがえる。また, 調査対象絵図にみる基礎的水辺空間の構成 を明らかするため, 上記 $\mathrm{E}$ 護岸, $\mathrm{F}$ 植栽, $\mathrm{G}$ 構築物における最 多要素を抽出した結果, 土堤に松が植樹され, 構築物として橋が 架かっている水辺空間構成が最多数描かれていたことがあきらか となった。つまり, 図一 4 が多用されている要素を集合した調査 対象絵図にみる基礎的水辺空間要素集合図である。多用されてい る要素を多分にもっている絵図を絵図 -1 , 絵図-2 にあげた。

（2）江戸人に人気を博した「江戸百景」における水辺の名所構 成景物要素

$\mathrm{H}$ 名勝系要素 $($ 表 $-1-($ ii $)-H)$

(1)山水要素

（３）－（i ）山水要素を骨子にした分析結果で詳細に触れる。 (2)八景的要素

八景的要素は, 絵図全体の約 36\%（28/78 点）に用いられて おり, 多数描かれた空間表現領域は, 日本橋領域（約 $18 \%: 5 / 2$ 8 点）であった。八景は, 「強い詩的映像喚起の力をもつ」 $\rfloor^{14)} も の$ であり, 小林享氏は,「各気象現象を効果的に見せるポイントが 押さえられれば，景観はより豊かな内容を持つようになる」 $\rfloor^{15)}$ と 指摘している。八景的景物は，「落雁，帰帆，晴嵐，暮雪，秋月， 夜雨, 晚鐘, 夕照のうち帰帆, 晚鐘のみが人事にかかわることで, 他の 6 景はすべて自然現象であり, 水辺の地で, 帰帆, 晚鐘の景

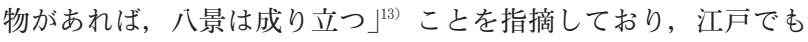
有効な景物であったことが伺える。

(3)俯瞰表現要素

調查対象絵図中約 51\%（40/78 点）に用いられており，多数 描かれた空間表現領域は, 独立型領域（約 15\%：6/40点）であっ た。『65：よし原日本堤』(絵図-3 $)^{1)}(\text { 絵図 }-4)^{8)}$ を例に挙げる と, 画中左上部に吉原を表現し, 日本堤の吉原へ向かう人々が江 戸名所として描かれており, 俯瞰表現要素の役割の 1 つに眺望性 と加えて, 絵地図 ${ }^{16)}$ としての効果があげられる。面的な地域の 歴史・風俗などの景物要素に水辺空間が付加することでさらに名 所性が䁔成されているように思われ，水辺空間と景物要素の密接 な関係性が伺える。

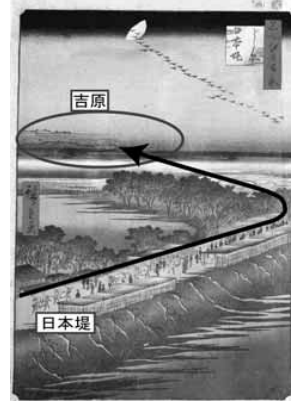

絵図-3 65：吉原日本堤

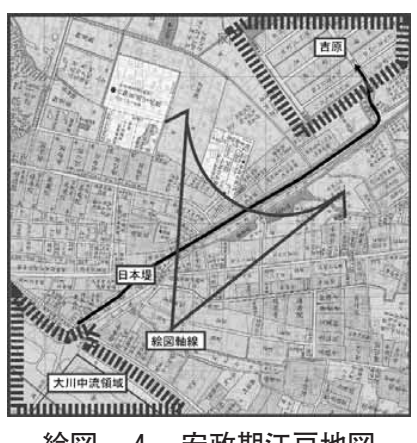

絵図-4 安政期江戸地図
I歳時系（表 $-1-$ (ii ) - I )

（3）－（ii）歳時系要素を骨子にした分析結果で詳細に触れる。 $\mathrm{J}$ 歴史文化（表 $-1-($ ii $)-J$ )

主題系（歴史文化）は，調査対象絵図すべてに描かれた名所構 成景物要素であった。宮尾しげお氏は，「浮世絵に表された景色 は，ある時は主役であり，ある時は，借景である。こうした場所

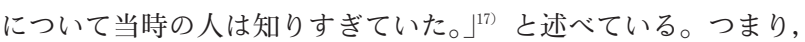
浮世絵に描かれた名所の背景に，年中行事，風俗など江戸庶民文 化によって画題が選定されていると推察され, 江戸の水辺空間之 水辺の名所を構成する「景物」との相互作用によって,「江戸百 景」における水辺名所が成立しているといえる。次項では, 水辺 の名所構成景物要素の山水要素及び, 歳時系要素を骨子とした分 析を行い, 水辺空間構成要素と水辺の名所構成景物要素の相互関 係分析を行う。

（3）水辺空間構成要素・水辺の名所構成景物要素の相互関係分 析結果

（i）山水要素を骨子にした分析結果

山水要素は, 絵図全体の約 33\%（26/78 点）に用いられてい る。多数描がかれた空間表現領域は, 日本橋領域（富士山 4 点）, 大川上流領域（筑波山 3 点・日光山々 1 点）・大川中流領域(富 士山 2 点・筑波 1 点・真乳山 1 点) の 3 領域であった。山水要素 が多用された水辺空間構成は，木杭土堤 $28 \%$ に植樹された松 （44\%）と架け橋（40\%）からなり（表－3参照), 図－4 調查対 象絵図にみる基礎的水辺空間要素集合図と近い構成になっている。 歳時系要素では, 富士山, 筑波山, 御殿山, 庭園築山などの遠近 の山々を望む花見（桜）の風景が多く描かれている（表一 -3 及び 
表ー 3 山水要素を骨子とした要素関係を示す集計表

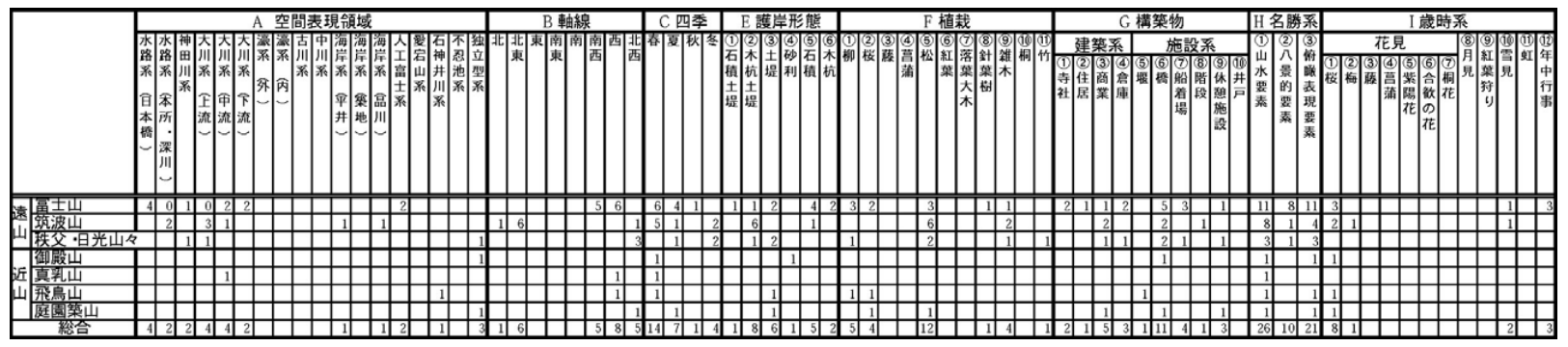

表ー4 歳時系要素を骨子とした要素関係を示す集計表

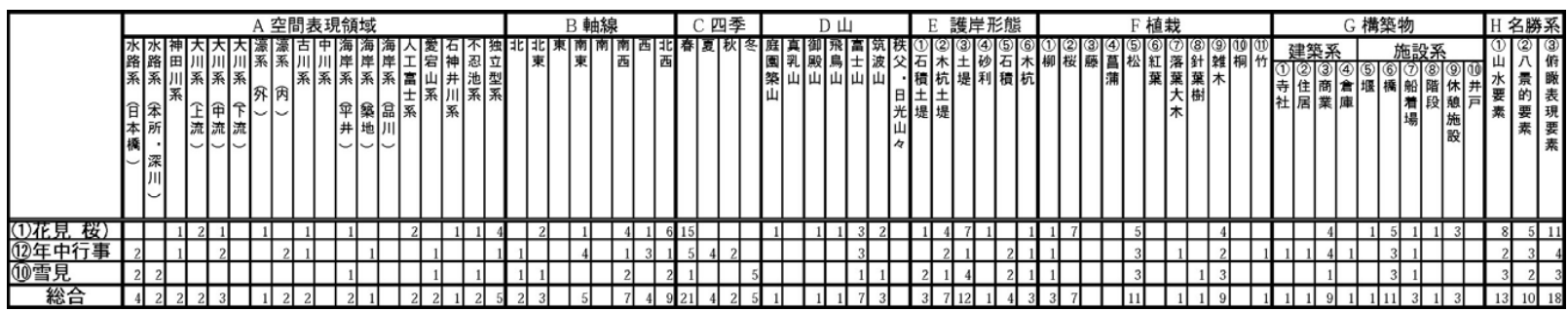

絵図 - 1 参照)。また, 富士・筑波の描かれた空間表現領域は, 大川下流領域は富士のみ（2 点）を望み, 上流領域は筑波のみ $(3$ 点), 中流領域は, 富士・筑波 ( ( 2 点・1 点) 同時に眺望が可能 な唯一の空間表現領域となっている。井田太郎氏は,「富士・筑 波の絵図が都市の祝祭的な空気, いわば江戸じまんを䁔成する装 置として使用される」18)ことや, 富士筑波の型が「都曾」の景物 として位置づけられ, 同時に江戸の風光明媚さを強調する景物で あったこと ${ }^{18)}$ につて指摘している。富士・筑波の二山を眺望で きた大川中流領域が 18 の空間表現領域中で最も多く描かれてい ることなどからも，風光明媚な領域であったことが伺える。また， 大川中流領域は, 吉原ルートにおける交通の輻輳点 ${ }^{7}$ であったこ とから, 『18:真乳山山谷堀夜景』や『69:御厩河岸』など吉原風 俗の影響を受けたとみられる絵図が多くみられ, 歳時系要素は,

大川水系領域内で，最多数描かれた領域であった。

(ii）歳時系要素を骨子にした分析結果

歳時系要素で多く描かれた景物要素順に挙げると, (1)花見 : 桜 (15 点) (2)年中行事 (11 点) (3)雪見（6 点）であり, 調查対象絵 図における歳時系要素に花見が最も愛用されていたことがあきら かとなった。花見が行なわれた水辺空間では, 遠近の山々が（約 $53 \% ： 8 / 15 ）$ 絵図に描かれ, 花見に山を望む水辺空間が多数み られる事は, 山水を骨子とした分析と一致する。花見, 年中行事, 雪見が行なわれた上位の水辺空間構成は, 土堤に松並木と架橋で あった。これは, 図 -4 調查対象絵図にみる基礎的水辺空間要素 集合図と一致する。調查対象絵図における水辺が,「基本的な水 辺の空間構成」に「歳時系要素」が表現される形で水辺の名所が 多数成立していることを示している。つまり「調査対象絵図の基 本的な水辺の空間構成」が, 景物要素の多様な变動を受容できる 柔軟な構成空間であったといえる。

\section{4.まとめ}

江戸人の人気を博した歌川広重「名所江戸百景」の全 119 点中, 93 点（約 79\%）に水辺が描かれており, 水辺空間では, 花見 （桜）や祭り, 雪見, 紅葉狩り, 月見など多種多様な自然環境亡 人の交流としての鑑賞媒体が描写されている。本研究は,「江戸 百景」に描かれた水辺と鑑賞媒体との関係について, その特性の 解明を行なった。その結果, 調査対象絵図の基本的な水辺空間 (図一4) が, 瑠璃の松と散華の桜にみられるような歴史・文化, 歳時系要素, 山水要素, 八景的要素など水辺の名所構成景物要素 を内包し, 景物要素の変動を多面的に受容できる柔軟な水辺空間
であったことを明らかにした。現代の河川計画では，水辺空間領 域に集中した計画が進められる傾向にあるが，「人と自然環境の 交流」を可能にする水辺空間を計画するためには，四季の移ろい， 歴史・文化，山水に打ける眺望軸線や，八景要素に見られる気象 変動などを効果的に創出させる水辺空間を成立させているステー ジとの相互作用を含めて再考する必要があると考えられる。本研 究は, 基礎的な水辺空間構成要素之水辺の名所構成景物要素を対 象に関係性の分析を行っている。今後, 各要素の小項目等につい て詳細な分析，さらに各要素ごとの関係性について分析を行なう と共に, 江戸人に好まれた絵図を拠り所とした現代都市空間に再 生しえるデイン手法の確立を目指してゆこうと考えている。

\section{引用文献}

1）宮尾しげお解説（1974）：名所江戸百景絵図：日本浮世絵体系 16 卷/ 17 卷

2 ) 成瀬不二雄（1998）: 葛飾北斎と歌川広重の風景版画：日本絵画の風 景表現, 309-320

3 ) 成瀬不二雄（1998）: 平安時代における名所絵の成立とその画題: 日 本絵画の風景表現, $21-28$

4 ）橋本政子・堀繁（1997）：江戸の河岸の空間デザインとその規範に関 する研究 : 第 32 回都市計画学会学術研究論文集, $283-288$

5 ）橋本政子・堀繁（1998）：日江戸の水辺の樹木・緑地の立地とそのデ ザイン規範：第 33 回日本都市計画学会学術研究論文集，655-660

6 ) 橋本政子・堀繁 (1999)：江戸の川岸の張り出し・引き込みとその効 果: 第 34 回都市計画学会学術研究論文集, $37-42$

7) 荒井歩（2000：江戸下町の水辺に打ける庶民の遊行動に関する研究： ランドスケープ研究 63(5), 639-642

8 ）児玉幸多監修（1994）：復元・江戸情報地図・安政期江戸地図：18541860 年縮尺 $1 / 6500:$ 朝日新聞社

9 ) 国土地理院（2002）：数值地図 $1 / 25000 ：$ 国土地理院

10）陸地測量部（1880）：東京近傍中部 $1 / 20000$ : 陸地測量部

11）渡部一二（2002）：水路の用と美：山海堂

12）樋口忠彦（1978）：風景と形：日本の美学 13，65-67

13）山田安彦編集 (2001) : 方位読み解き事典：柏書房, 35-36

14）芳賀徹（1986）：比較文学研究 50 号, 4

15）小林享（1987）：景観の移ろい効果に関する基礎的研究：造園雑誌 50 (5), $263-268$

16）成瀬不二雄（1998）：風景表現における桃山時代日本絵画の風景表現： 日本絵画の風景表現, $146-154$

17）宮尾しげお解説（1974）：名所江戸百景絵図：日本浮世絵体 17，66

18）桐敷眞次郎（1971）：天正・慶長・寛永期江戸市街地建設における景 観設計：都市研究報告 24 號

19）井田太郎（2005）：富士筑波という型の成立と展開：國華第千三百十 五號 